\title{
OCURRENCE OF STAPHYLOCOCCUS AUREUS AND MULTIPLEX PCR DETECTION OF CLASSIC ENTEROTOXIN GENES IN CHEESE AND MEAT PRODUCTS
}

\author{
Marcia Regina Pelisser ${ }^{1,2}$; Cátia Silene Klein ${ }^{3}$; Kelen Regina Ascoli ${ }^{3}$; Thaís Regina Zotti \\ Ana Carolina Maisonnave Arisi ${ }^{1 *}$
'Departamento de Ciência e Tecnologia de Alimentos, Centro de Ciências Agrárias, Universidade Federal de Santa Catarina, Florianópolis, SC, Brasil; ${ }^{2}$ Universidade do Contestado, Concórdia, SC, Brasil; ${ }^{3}$ EMBRAPA - Suínos e Aves, Concórdia, SC, Brasil.

Submitted: March 07, 2008; Returned to authors for corrections: June 29, 2008; Approved: November 02, 2008.

\begin{abstract}
Multiplex PCR was used to investigate the presence of enterotoxins genes (sea, seb, sec, sed and see) and femA gene (specific for Staphylococcus aureus) in coagulase-positive staphylococci (CPS) isolated from cheese and meat products. From 102 CPS isolates, 91 were positive for femA, 10 for sea, 12 for sed and four for see.
\end{abstract}

Key words: Staphylococcus aureus, enterotoxins, multiplex PCR

Staphylococcus aureus is the predominant specie involved in staphylococcal food-poisoning outbreaks, although other coagulase-positive Staphylococci, such as $S$. intermedius and $S$. hyicus, may also be enterotoxigenic $(5,34,35)$. S. aureus may produce a large variety of enterotoxins (A, B, C, D, E, G, H, I, J, $\mathrm{K}, \mathrm{L}, \mathrm{M}, \mathrm{N}, \mathrm{O}, \mathrm{P}, \mathrm{Q}, \mathrm{R}$ and $\mathrm{U}$ ), but $95 \%$ of poisoning outbreaks are caused by classical enterotoxins: A, B, C, D and E (24). Enterotoxin A is the most frequently produced $(8,21)$. Staphylococcal enterotoxins are thermostable and also resistant to gastrointestinal proteases such as pepsin, explaining its ability in remaining active after ingestion $(7,8,36)$.

The amount of staphylococcal enterotoxins required for establishment of typical symptoms of food poisoning is very low, ranging from $20 \mathrm{ng}$ to $1 \mu \mathrm{g}$ (32). Which corresponds to approximately $10^{5}$ staphylococci colony-forming units per gram of food (19). Several studies evaluated the capability of staphylococcal strains isolated from foods to produce the classical enterotoxins A, B, C, D and E $(2,5,8,13,15,18,20,26,31,33)$. In Brazil, several studies reported counts of coagulase-positive Staphylococci above the maximum levels allowed by the Brazilian legislation (11) in sausages (colonial sausage), milk and milk products $(1,3-6,10,12-14,23,25)$.
The aim of the present work was to evaluate the presence of by coagulase-positive Staphylococci (CPS) in meat and milkderived products commercialized in Santa Catarina, SC, Brazil and to detect the presence of genes for classical staphylococcal enterotoxins A, B, C, D and E (sea, seb, sec, sed and see) and for gene $f e m \mathrm{~A}$, specific for $S$. aureus species, using multiplex PCR.

A total of 72 food samples including mozzarella (15 samples), American cheese (15 samples), colonial cheese (15 samples), colonial sausage ( 18 samples) and salaminho ( 09 samples) were collected from markets in Alto Uruguai Catarinese region (AMAUC), in Santa Catarina state, Brazil, from 2005 to 2007.

The mozzarella (A, B, C) and American cheese brands analyzed in this work are under Federal Inspection Service (SIF), while colonial cheese brands are under different inspection services: State Inspection (SIE) (G brand), Municipal Inspection (SIM) (H brand) and SIF (I brand). Five (A, B, C, D, E) out of six brands of colonial sausages are inspected by SIE, and G brand is inspected by SIM (Concórdia - SC). Salaminho brands (A, B, C) are inspected by SIF.

For $S$. aureus enumeration (17), serial dilutions of food homogenates were plated on Baird Parker agar (Oxoid) with $5 \%$ egg yolk tellurite emulsion (Oxoid) and incubated at $35^{\circ} \mathrm{C}$ for

*Corresponding Author. Mailing address: Departamento de Ciência e Tecnologia de Alimentos, Centro de Ciências Agrárias, Universidade Federal de Santa Catarina. Av. Admar Gonzaga, 1346 CEP 88034-001 Florianópolis - SC, Brasil. Tel.: 55 4837215382. E-mail: arisi@cca.ufsc.br 
48 h. After this period, typical colonies (circular, smooth, convex, gray to jet-black, frequently with light-colored (off-white) margin, surrounded by opaque zone and frequently with an outer clear zone) were counted and five colonies were transferred to MacConkey agar (Oxoid) and blood agar. Colonies that grew in blood agar but not in MacConkey were tested for Gram coloration, coagulase, catalase, oxidase, urease and maltose.

Total DNA was extracted from $5 \mathrm{~mL}$ of a coagulase-positive staphylococcal culture grown at $35^{\circ} \mathrm{C}\left( \pm 2^{\circ} \mathrm{C}\right)$ for $16-24 \mathrm{~h}$ in Brain Heart Infusion (Merck) broth. DNA was isolated using the WizardÒ Genomic DNA Purification Kit (Promega Corporation, Madison, WI, USA) and lisozyme $10 \mathrm{mg} \cdot \mathrm{mL}^{-1}$ (Sigma Aldrich). Enterotoxigenic $S$. aureus strains ATCC 13565 (sea), ATCC 14458 (seb), ATCC 19095 (sec), ATCC 23235 (sed) e ATCC 27664 (see) were used as positive controls and Staphylococcus xylosus ATCC 29971 as negative control.

Detection of specific genes for S. aureus (femA) and for enterotoxins A, B, C, D, and E was carried out according to Mehrotra, Gehua, Johnson (27), with some modifications, yelding the expected amplicons: $102 \mathrm{bp}$ for sea, $132 \mathrm{bp}$ for fem $\mathrm{A}$, $164 \mathrm{bp}$ for seb, $209 \mathrm{bp}$ for see, $278 \mathrm{bp}$ for sed, $451 \mathrm{bp}$ for sec.

For multiplex PCR detection of sec and fem A genes, amplification reactions were performed in final volume of 25 $\mathrm{mL}$ containing PCR buffer (20 mM Tris-HCl, $\mathrm{pH} 8.4,50 \mathrm{mM}$ $\mathrm{KCl}), 1.5 \mathrm{mM} \mathrm{MgCl}_{2}, 0.2 \mathrm{mM}$ of each dNTP, $0.4 \mathrm{mM}$ of each primer, 1.25 U Taq DNA polymerase and 100-300 ng of template DNA. Reactions were carried out in Minicycler ${ }^{\mathrm{TM}}$ (MJ Research, Inc. Watertown, MA) with the following program: initial denaturation at $94^{\circ} \mathrm{C}$ for 5 min followed by 35 cycles of $94^{\circ} \mathrm{C}$ for $2 \mathrm{~min}, 57^{\circ} \mathrm{C}$ for $2 \mathrm{~min}$ and $72^{\circ} \mathrm{C}$ for $60 \mathrm{~s}$ with a final extension at $72^{\circ} \mathrm{C}$ for $7 \mathrm{~min}$.

For multiplex PCR detection of sea, seb, sed, see and femA genes, amplification reactions were performed in final volume of $50 \mathrm{~mL}$ containing PCR buffer (20 mM Tris- $\mathrm{HCl}, \mathrm{pH} 8.4,50 \mathrm{mM}$ $\mathrm{KCl}$ ), $3 \mathrm{mM} \mathrm{MgCl}, 0.2 \mathrm{mM}$ of each dNTP, $400 \mathrm{nM}$ of each primer, 1.25 U Taq DNA polymerase and 100-300 ng of template DNA. Amplification profile was standardized in $94^{\circ} \mathrm{C}$ for $5 \mathrm{~min}$ followed by 35 cycles of $94^{\circ} \mathrm{C}$ for $2 \mathrm{~min}, 52^{\circ} \mathrm{C}$ for $2 \mathrm{~min}$ and $72^{\circ} \mathrm{C}$ for $3 \mathrm{~min}$ with a final extension at $72^{\circ} \mathrm{C}$ for $7 \mathrm{~min}$.

PCR products were separated by electrophoresis at $80 \mathrm{~V}$ for $70 \mathrm{~min}$ in $2 \%$ agarose gel and stained with ethidium bromide. Gels were visualized in a UV transilluminator and images were digitalized with a digital camera (CANON Powershot A70).

Presence of coagulase-positive staphylococci (CPS) was detected in 33 out of 72 analyzed samples. In American and colonial cheeses, from 30 samples analyzed, 19 presented contamination by CPS. However, presence of CPS was not detected in the 15 mozzarella samples. $28.8 \%$ of samples contaminated with CPS presented counts with levels above $10^{3}$ CFU. $\mathrm{g}^{-1-}$ which is the upper limit established by RDC $\mathrm{n}^{\circ} 12$ of the Brazilian National Sanitary Control Agency (11). Counts in samples inspected by municipal, state and federal inspection services differed significantly, being those in SIF inspected samples significantly lower ( mean of $1.4 \times 10^{3} \mathrm{CFU} \cdot \mathrm{g}^{-1}$ ) than the samples inspected by the other two services $\left(1.5 \times 10^{5}\right.$ and $1.7 \times 10^{5}$ CFU.g ${ }^{-1}$, for SIE and SIM, respectively). In 6 samples of colonial cheese, CPS counts were above $10^{5} \mathrm{CFU} \cdot \mathrm{g}^{-1}$. According to FDA (19), in foods with such high counts of CPS the presence of staphylococcal enterotoxin is likely. In 9 out of 18 samples of colonial sausages, concentration of CPS was above the limit established by the Brazilian legislation (11), and in 6 samples, the counts were above than $10^{5}$ CFU.g-1 . All salaminho samples were negative for CPS.

From the 200 Staphylococcus spp. isolates, 116 originated from American and colonial cheeses and 84 from colonial sausage. $102(51 \%)$ strains were characterized as coagulasepositive staphylococci (CPS), being 67 from colonial sausage and 35 from American and colonial cheeses. The remaining 98 isolates (49\%) were coagulase-negative staphylococci (Table 1).

CPS isolates were analyzed by multiplex PCR in order to detect femA, sea, seb, sec, sed and see genes (Fig. 1). 91 out of 102 isolates were positive for femA gene. All femA gene negative CPS isolates (11 isolates) have been isolated from colonial sausage. The sed, sea and see genes were detected in 12, 10 and 4 isolates, respectively (Table 1). None of the isolates was positive for $\mathrm{seb}$ or $\mathrm{sec}$ genes.

The fem A gene was detected in all 35 CPS isolates from cheeses, confirming the biochemical characterization. From cheese samples, sed was detected in ten isolates and see was detected in one isolate (Tab.1). In sed gene positive isolates, amplification of fragments with 600 and $700 \mathrm{bp}$ was also observed (Fig.1A). The presence of these two extra fragments was observed only when the sed fragment was also present. Other authors have also reported the presence of unexpected fragments in some dairy products evaluated by multiplex PCR for the presence of enterotoxin genes (16).

Among the $56 \mathrm{CPS}$ isolates from colonial sausage that were positive for femA, seven were also positive for sea and one for sed (Fig. 1B, Table 1). Three isolates amplified the enterotoxin genes sea and see simultaneously.

Several authors have also reported that enterotoxin genes sea and sed are the most common in staphylococci isolated from foodstuffs $(5,7,8,30,33)$. In Brazil, Carmo et al. investigated the presence of staphylococci in minas fresh cheese and raw milk and observed that the isolates were able to produce enterotoxins A, B and C (13). Cheese produced in Serra da Canastra, MG, also contained $S$. aureus isolates able to produce enterotoxins B and C (9).

Detection of the enterotoxin genes in the CPS isolates coming from a food is not an indication that the toxins are effectively present in this food. Morandi et al. (28) evaluated 107 CPS isolates from dairy products, and observed that enterotoxin genes were detected in $67 \%$ isolates, but only $52 \%$ of the isolates were capable to produce enterotoxins. These 
Table 1. Prevalence of femA, sea, seb, sec, sed and see genes in coagulase-positive Staphylococci strains isolated from foods.

\begin{tabular}{lcccccccc}
\hline Type of Food & $\begin{array}{c}\text { Number of } \\
\text { Isolates }\end{array}$ & CPS & $\begin{array}{c}\text { CPSfemA } \\
\text { positive }\end{array}$ & $\begin{array}{c}\text { CPS sea } \\
\text { positive }\end{array}$ & $\begin{array}{c}\text { CPS se } \\
\text { bpositive }\end{array}$ & $\begin{array}{c}\text { CPS sec } \\
\text { positive }\end{array}$ & $\begin{array}{c}\text { CPS sed } \\
\text { positive }\end{array}$ & $\begin{array}{c}\text { CPS see } \\
\text { positive }\end{array}$ \\
\hline Colonial and American Cheeses & 116 & 35 & 35 & 0 & 0 & 0 & 11 & 1 \\
Colonial Sausage & 84 & 67 & 56 & 10 & 0 & 0 & 1 & $3^{*}$ \\
\hline Total & 200 & 102 & 91 & 10 & 0 & 0 & 12 & 4 \\
\hline
\end{tabular}

* These strains were also positive for the presence of sea gene.

CPS $=$ Coagulase-positive Staphylococci .

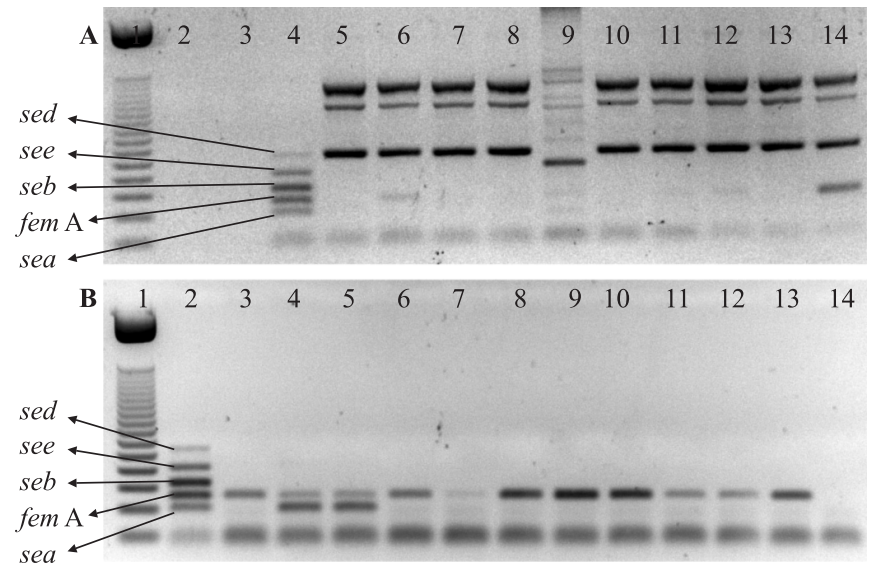

Figure 1. Multiplex PCR of CPS strains isolated from A) cheese, B) colonial sausage. A) lane 1: Ladder 50bp (Promega); lane 2: water; lane 3: negative control (Staphylococcus xylosus ATCC 29971); lane 4: positive control (mix of four ATCC strains 13565 sea, 14458 seb, 23235 sed and 27664 see); lanes 5 - 14: S. aureus strains isolated from cheese. B) Lane 1: Ladder $50 \mathrm{bp}$ (Promega); lane 2: positive control (mix of four ATCC strains 13565 sea, 14458 seb, 23235 sed and 27664 see); lanes 3 - 13: S. aureus isolated from colonial sausage; lane 14: negative control (Staphylococcus xylosus ATCC 29971).

authors reported that the results obtained by multiplex PRC and immunoassay tests were in agreement when tested for the presence of enteroxins A, C and D (16).

Results of the present work confirm that multiplex PCR is a rapid and sensitive method for screening of enterotoxigenic coagulase-positive Staphylococci, being highly specific. Results also indicate that better hygiene practices and better inspection are required in the production of the foods included in the study.

\section{ACKNOWLEDGEMENTS}

This work was supported by FAPESC (Universal 2006, process FCTP1378/000), UnC and UFSC.

\section{RESUMO}

\section{Ocorrência de Staphylococcus aureus e detecção por PCR multiplex de genes de enterotoxinas clássicas em queijo e derivados cárneos}

PCR multiplex foi empregado para investigar a presença de genes de enterotoxinas estafilocócicas (sea, seb, sec, sed e see) e do gene femA, específico para S.aureus, em cepas de estafilococos coagulase positiva (ECP) isoladas de queijos e derivados cárneos. De 102 cepas, 91 foram positivas para fem $\mathrm{A}$, 10 para sea, 12 para sed e 4 para see.

Palavras-chave: Staphylococcus aureus; enterotoxinas, PCR multiplex

\section{REFERENCES}

1. Adesiyum, A.A.; Webb, L.A.; Romain, H.T. (1998). Prevalence and characteristics of Staphylococcus aureus strains isolated from bulk and composite milk and cattle handlers. J. Food Prot. 61: 629-632.

2. Adwan, G.; Abu-Shanab, B.; Adwan, K. (2005). Enterotoxigenic Staphylococcus aureus in raw milk in the North of Palestine. $J$. Biology, 29: 229-232.

3. Almeida Filho, E.S.; Nader Filho, A. (2000). Ocorrência de Staphylococcus aureus em queijo tipo "frescal". Rev. Saúde Pública, 34: $578-80$.

4. Anunciação, L.L.C.; Linardi, W.R.; Carmo, L.S.; Bergdoll, M.S. (1994). Production of staphylococcal enterotoxin A in white cheese. Braz. J. Microbiol. 25: 68-71.

5. Aragon-Alegro, L.C.; Konta, E.M.; Suzuki, K.; Silva, M.G.; Fernandes Júnior, A.; Raal, R.; Rall, V.L.M. (2007). Occurrence of coagulasepositive Staphylococcus in various food products commercialized in Botucatu, SP, Brazil and detection of toxins from food and isolated strains. Food Control, 18: 630-634.

6. Araújo, V.S.; Pagliares, V.A.; Queiroz, M.L.P.; Freitas-Almeida, A.C. (2002). Occurrence of Staphylococcus and enteropathogens in soft cheese commercialized in the city of Rio de Janeiro, Brazil. J. Appl. Microbiol. 92: 1172-1177.

7. Atanassova, V.; Meindl, A.; Ring, C. (2001). Prevalence of Staphylococcus aureus and staphylococcal enterotoxins in raw pork and uncooked smoked ham - a comparison of classical culturing detection and RFLP-PCR. Int. J. Food Microbiol. 68: 105-113.

8. Balaban, N.; Rasooly, A. (2000). Review staphylococcal enterotoxins. Int. J. Food Microbiol. 61: 1-10.

9. Borelli, B.M.; Ferreira, E.G.; Lacerda, I.C.A.; Santos, D.A.; Carmo, L.S.; Dias, R.S.; Silva, M.C.C. (2006). Enteroxigenic Staphylococcus 
spp. and other microbial contaminants during production of canastra cheese, Brazil. Braz. J. Microbiol. 37: 545-550.

10. Borges, M.F.; Siqueira, R.S. de; Bittencourt, A.M. ; Vanetti, M.C.D.; Gomide, L.A.M. (1999). Occurrence of Listeria monocytogenes in salami. Rev. Microbiol. 30: 362-64.

11. BRASIL. Ministério da Saúde, Agência Nacional de Vigilância Sanitária (2001). Regulamento Técnico sobre padrões microbiológicos para alimentos. Resolução RDC n ${ }^{\circ} 12$, de 02 de janeiro de 2001. Diário Oficial da União, Brasília, DF.

12. Carmo, L.S.; Bergdoll, M.S. (1990). Staphylococcal food poisoning in Belo Horizonte (Brazil). Braz. J. Microbiol. 21: 320-323.

13. Carmo, L.S.; Dias, R.S.; Linardi, V.R.; Sena, M.J.; Santos, D.A.; Faria, E.; Pena, E.C.; Jett, M.; Heneine, L.G. (2002). Food poisoning due to enterotoxigenic strains of Staphylococcus present in Minas cheese and raw milk in Brazil. Food Microbiol., 19: 9-14.

14. Chapaval, L.; Moon, D.H.; Gomes, J.E.; Duarte, F.R.; Tsai, S.M. (2006). Use of pcr to detect classical enterotoxins genes (ent) and toxic shock syndrome toxin-1 gene (tst) in staphylococcus aureus isolated from crude milk and determination of toxin productivities of $S$. aureus isolates harboring these genes. Arq. Inst. Biol. São Paulo, 73: 165-169.

15. Cunha Neto, A.; Silva, C.G.M.; Stamford, T.L.M. (2002). Staphylococcus enterotoxigênicos em alimentos in natura e processados no estado de Pernambuco, Brasil. Ciênc. Tecnol. Alim. 22: 263-275.

16. Cremonesi, P.; Luzzana, M.; Brasca, M.; Morandi, S.; Lodi, R.; Vimercati, C.; Agnellini, D.; Caramenti,G.; Moroni, P.; Castiglioni, B. (2005). Development of a multiplex PCR assay for the identiûcation of Staphylococcus aureus enterotoxigenic strains isolated from milk and dairy products. Mol. Cell Probes, 19: 299305 .

17. Downes, F.P.; Ito, K. (eds.) (2001). Compendium of methods for the microbiological examination of food. 4.ed. APHA Press, Washington: DC.

18. Ercolini, D.; Blaiotta, G.; Fusco, V.; Coppola, S. (2004). PCR-based detection of enterotoxigenic Staphylococcus aureus in the early stages of raw milk cheese making. J. Appl. Microbiol. 6:1090-1096.

19. U.S. Food and Drug Administration. (2001). Foodborne pathogenic microorganisms and Natural Toxins. Available at: http:// www.cfsan.fda.gov.Acessed 12 jul 2007.

20. Fueyo, J.M.; Martin, M.C.; Gonzalez-Hevia, M.A.; Mendoza, M.C. (2001). Enterotoxin production and DNA fingerprinting in Staphylococcus aureus isolated from human and food samples. Relations between genetic types and enterotoxins. Int. J. Food Microbiol. 67: 139-145.

21. Hwang, S.Y.; Kim, S.Y.; Jang, E.J.; Kwon, N.H.; Park, Y.K.; Koo, H.C.; Jung, W.K.; Kim, J.M.; Park, Y.H. (2007). Novel multiplex PCR for the detection of the Staphylococcus aureus superantigen and its application to raw meat isolates in Korea. Int. J. Food Microbiol. 117: 99-105.

22. Kim, J.S.; Lee, G.G.; Park, J.S.; Jung, Y.H.; Kwak, H.S.; Kim, S.B.; Nam, Y.S.; Kwon, S.T. (2007). A novel multiplex PCR assay for rapid and simultaneous detection of five pathogenic bacteria: Escherichia coli 0157:H7, Salmonella, Staphylococcus aureus, Listeria monocytogenes, and Vibrio parahaemolyticus. J. Food Prot. 70(7): 1656-62.
23. Lamaita, H.C.; Cerqueira, M.M.O.P.; Carmo, L.S.; Santos, D.A.; Penna, C.F.A.M.; Souza, M.R. (2005). Contagem de Staphylococcus spp. e detecção de enterotoxinas estafilocócicas e toxina da síndrome do choque tóxico em amostras de leite cru refrigerado. Arq. Bras. Med. Vet. Zootec. 57: 702-709.

24. Letertre, C.; Perelle, S.; Dilasser, F.; Fach, P. (2003). Identification of a new putative enterotoxin SEU encoded by the egc cluster of Staphylococcus aureus. J. Appl. Microbiol. 95: 38-43.

25. Loguercio, A.P.; Aleixo, J.A.G. (2001). Microbiologia de queijo Minas Frescal produzido artesanalmente. Ciência Rural, 31: 1063-1067.

26. Martín, M.C; González-Hevia, M.A.; Mendoza, M.C. (2003). Usefulness of a two-step PCR procedure for detection and identification of enterotoxigenic staphylococci of bacterial isolates and food samples. Food Microbiol. 20: 605-610.

27. Mehrotra, M.; Wang, G.; Johnson,W.M. (2000). Multiplex PCR for Detection of Genes for Staphylococcus aureus Enterotoxins, Exfoliative Toxins, Toxic Shock Syndrome Toxin 1, and Methicillin Resistance. J. Clin. Microbiol. 38: 1032-1035.

28. Morandi, S.; Brasca, M.; Lodi, R.; Cremonesi, P.; Castiglioni, B. (2007). Detection of classical enterotoxins and identification of enterotoxin genes in Staphylococcus aureus from milk and dairy products. Vet. Microbiol. 124: 66-72.

29. Morot-Bizot, S.C.; Talon, R.; Leroy, S. (2004). Development of a multiplex PCR for the identiûcation of Staphylococcus genus and four staphylococcal species isolated from food. J. Appl. Microbiol. 97: 1087-1094.

30. Nájera-Sánchez, G.; Maldonado-Rodríguez, R.; Olvera, P.R.; Garza, L.M. de La (2003). Development of two multiplex polymerase chain reaction for the detection of enterotoxigenic strains of Staphylococcus aureus isolated from foods. J. Food Prot. 66: 10551062.

31. Nema, V.; Agrawal, R.; Kamboj, D.V.; Goel, A.K.; Singh, L. (2007). Isolation and characterization of heat resistant enterotoxigenic Staphylococcus aureus from a food poisoning outbreak in Indian subcontinent. Int. J. Food Microbiol. 117: 29-35.

32. Normanno,G.; La Salandra, G.; Dambrosio, A.; Quaglia, N.C.; Corrente, M.; Parisi, A.; Santagada, G.; Firinu, A.; Crisetti, E.; Celano, G.V. (2007). Occurrence, characterization and antimicrobial resistance of enterotoxigenic Staphylococcus aureus isolated from meat and dairy products. Int. J. Food Microbiol. 115: 290-296.

33. Portocarrero, S.M.; Newman, M.; Mikel, B. (2002). Staphylococcus aureus survival, staphylococcal enterotoxin production and shelf stability of country-cured hams manufactured under different processing procedures. Meat Sci. 62: 267-273.

34. Silva, W.P.; Silva, J.A.; Macedo, M.R.P.; Araújo, M.R.; Mata, M.M.; Gandra, E.A. (2003). Identification of Staphylococcus aureus, S. intermedius and $S$. hyicus by PCR amplification of coa and nuc genes. Braz. J. Microbiol. 34: 125-127.

35. Silva, W.P.; Destro, M.T.; Landgraf, M.; Franco, B.D.G.M. (2000). Biochemical characteristics of typical and atypical Staphylococcus aureus in mastitic milk and environmental samples of Brazilian dairy farms. Braz. J. Microbiol. 31: 103-106.

36. Soriano, J.M.; Font, G.; Moltó, J.C.; Mañes, J. (2002). Enterotoxigenic staphylococci and their toxins in restaurant foods. Trends Food Sci. Technol. 13: 60-67. 